\title{
PERBANDINGAN KURIKULUM PENDIDIKAN DASAR DAN MENENGAH DI INDONESIA DITINJAU DARI SEGI DESAIN, METODOLOGIS, DAN EVALUASI, 1968-2006
}

\author{
Oleh: Karnadi *)
}

\section{Abstrak}

This qualitative descriptive research was trying to find the basic differences of national curriculum of primary and secondary school in Indonesia since 1968 until 2006. It was a library research, and conducted on September 2007 in Jakarta. The observed differences were curriculum design, methodological approach, and evaluation. One of factors of curriculum change was the differences of angle to see the education itself. The differences of curriculum design and methodological approach were structure of contents and the ways to implement the instructional in classes. Meanwhile, the differences of evaluation were the existence of instrument of evaluation and the way to evaluate the student's instructional process and results.

Key words: kurikulum, metodologis, evaluasi, human capital.

\section{A. PENDAHULUAN}

\section{Latar Belakang}

Pendidikan pada dasarnya memberikan bimbingan yang sistematis yang mengarahkan seseorang menjadi dewasa dan mandiri. Dalam pelaksanan bimbingan itu diperlukan pedoman. Pedoman inilah yang disebut dengan kurikulum. Kurikulum memiliki peran dan kedudukan strategis yang menentukan antara lain tujuan, proses pembelajaran, sarana dan prasarana, buku dan sumber belajar, guru, manajemen, standar kompetensi, standar kelulusan, dan evaluasi. Kurikulum merupakan isi suatu pendidikan yang harus mampu memecahkan masalah, dan menjawab tantangan serta perkembangan cepat yang terjadi di masyarakat. Dalam konteks ini, pengembangan kurikulum merupakan bagian dari upaya dari pemecahan masalah yang timbul dari proses pendidikan. Dalam bidang teknologi, pengembangan kurikulum adalah bagian tak terpisahkan dari teknologi pendidikan secara menyuluruh. Di samping itu, kurikulum semestinya dilihat sebagai awal dari pemecahan masalah yang mungkin timbul dalam proses pendidikan.

Keunggulan suatu negara dapat dilihat kurikulum pendidikan. Dari kurikulum pendidikan inilah proses pendidikan berjalan untuk melahirkan manusia yang terdidik sebagai human capital atau

*) Drs.Karnadi, MRDM., adalah staf BidangTeknologi Komunikasi pada Pusat Teknologi Informasi dan Komunikasi Pendidikan-Kementerian Pendidikan Nasional (Pustekkom-Kemendiknas). 
kualitas sumber daya manusia dalam membangun bangsa dan negara. Dalam sejarah pendidikan Indonesia, kurikulum pendidikan dasar dan menengah yaitu pada tingkatan Sekolah Dasar atau yang sederajat, Sekolah Menengah Pertama atau yang sederajat, dan Sekolah Menengah Atas atau yang sederajat, telah mengalami perubahan secara signifikan. Menurut majalah Pena Pendidikan, negara kita mencatat telah terjadi delapan kali perubahan kurikulum yaitu kurikulum 1947, kurikulum 1952, kurikulum 1964, kurikulum 1968, kurikulum 1975, kurikulum 1984, kurikulum 1994, Kurikulum Berbasis Kompetensi atau kurikulum 2004, dan kurikulum Standar Isi/Standar Kelulusan (S/I/SKL) atau kurikulum 2006 (Pena Pendidikan, 2006).

Reaksi masyarakat terhadap perubahan kurikulum tersebut amatlah beragam. Berbagai argumentasi dibuat oleh berbagai ahli dalam menanggapi perubahan kurikulum. Salah satunya adalah pemeo yang timbul dari masyarakat yaitu 'ganti menteri ganti kurikulum'. Namun terlepas dari polemik itu, perubahan kurikulum memang harus terjadi apalagi pada era globalisasi ini yang ditandai oleh persaingan ketat, menguatnya demokratisasi, komunikasi dan informasi tanpa batas, dan perubahan yang sangat cepat dalam berbagai kehidupan.

Ini adalah hal menarik yang terjadi dalam pendidikan Indonesia di mana setiap perubahan kurikulum ditandai dengan polemik yang berkepanjangan karena di sisi lain perubahan kurikulum tersebut menimbulkan implikasi yang signifikan bagi masyarakat. Implikasinya adalah biaya yang harus ditanggung masyarakat pengguna pendidikan seperti membeli buku-buku baru, seragam baru, alat-alat pembelajaran, pembayaran uang sekolah atau sumbangan pembayaran pendidikan.

\section{Perumusan Masalah}

Pembatasan masalah dalam penelitian ini adalah perubahan kurikulum pendidikan dasar dan menengah sejak tahun 1968 s.d 2006. Pertanyaan penelitian ini adalah apa perbedaan-perbedaan yang mendasar dari kurikulum pendidikan dasar dan menengah di Indonesia sejak 1968-2006 ditinjau dari segi desain kurikulum, pendekatan metodologis, dan evaluasi.

\section{Tujuan Penulisan}

Tujuan penelitian ini adalah untuk mengetahui perbedaan-perbedaan yang mendasar dari kurikulum pendidikan dasar dan menengah di Indonesia sejak 1968-2006 dari segi desain kurikulum, pendekatan metodologis, dan evaluasi.

Pembahasan kurikulum pada artikel ini adalah dimulai sejak tahun 1968 hingga tahun 2006. Alasan mengapa dimulai sejak kurikulum tahun 1968 adalah karena ketersediaan dan kemudahan sumber pustaka mengenai perkembangan kurikulum pendidikan di Indonesia. Penulis kesulitan memperoleh data dan informasi menganai sumber pustaka perkembangan kurikulum di samping itu kelengkapan dan keakuratan sumber pustaka mengenai kurikulum sebelum tahun 1968 sulit diperoleh. Oleh karena itu, penulis membahas perrbedaan-perbedaan mendasar kurikulum pendidikan di Indonesia dimulai sejak tahun 1968.

\section{Metode Penelitian}

Penelitian ini adalah bersifat deskriptif kualitatif, mengandalkan library research dengan mengoleksi data dan informasi yang relevan terhadap topik penelitian. Data dan informasi yang terkumpul dianalisis secara deskriptif.

\section{Teori/Konseptual}

Secara etimologi, kurikulum berasal dari bahasa Yunani, yaitu curere berarti jarak tempuh lari. Istilah ini bermula pada cabang olahraga, kemudian dipakai dalam bidang pendidikan yaitu sejumlah mata pelajaran di sekolah. Webster's International Dictionary, mendefinisikan kurikulum sebagai course, a specified fixed course of study, as in a school or college, as one leading to a degree. 
Menurut Undang-Undang nomor 20 tahun 2003 tentang sistem pendidikan nasional, kurikulum adalah seperangkat rencana dan pengaturan mengenai tujuan, isi, dan bahan pelajaran serta cara yang digunakan sebagai pedoman penyelenggaraan kegiatan pembelajaran untuk mencapai tujuan pendidikan tertentu.

Hilda Taba memberikan pengertian kurikulum sebagai sesuatu yang direncanakan untuk pelajaran anak. Lebih jauh Taba, memandang kurikulum sebagai produk, program pelajaran, materi pelajaran, dan pengalaman (Hilda Taba dalam S Nasution, 2001). Sebagai produk, kurikulum adalah hasil karya para pengembang kurikulum yang dikemas menjadi sebuah buku atau pedoman kurikulum yang berisi sejumlah mata pelajaran yang harus diajarkan. Kurikulum sebagai program, yaitu alat yang dilakukan oleh sekolah untuk mencapai tujuan, yang dianggap dapat mempengaruhi perkembangan siswa. Sebagai pengalaman, kurikulum harus memberikan pengalaman belajar kepada siswa.

Oleh karena itulah untuk dapat melihat bangunan kurikulum dapat dilihat sedikitnya pada tujuan kurikulum, struktur isi kurikulum, metodologis, dan cara evaluasi. Tujuan merupakan aspek penting dalam bangunan kurikulum. Setiap kurikulum memiliki tujuan pendidikan yang telah ditetapkan. Keberhasilan proses pendidikan berhasil bila tujuan kegiatan pendidikan dapat dilaksanakan sesuai dengan apa yang telah dirumuskan (Ahmad, 1999). Oleh karena itu, kurikulum dengan tujuan pendidikan tak dapat dipisahkan. Dia menjadi lekat dan bila dikaitkan dengan proses pendidikan tujuan kurikulum atau kurikulum itu sendiri dapat dikatakan sebagai raison d'etre dalam proses pembelajaran dan pendidikan. Dia dianggap sebagai sign posting, pemberi arah, penunjuk, kompas bagi proses pembelajaran yang diselenggarakan baik lembaga formal maupun non formal. Kurikulum memberikan gambaran jelas berencana bagaimana dan apa saja yang harus dilakukan dalam proses belajar mengajar yang dilakukan oleh pendidik dan anak didik.

Di dalam kurikulum harus ada struktur materi pelajaran yang menjadi susunan dan sekaligus isi kurikulum itu sendiri yang akan dijabarkan oleh pendidik (guru) kepada anak didik. Struktur ini adalah berfungsi sebagai alat yang harus menjamin bahwa tujuan pendidikan yang ditentukan dapat tercapai. Hal ini berarti bahwa penyusunan kurikulum terutama dalam hal penentuan isi bahan pengajaran baik yang memperkuat bidang studi maupun pokok bahasan, harus berdasarkan tujuan-tujuan yang telah ditetapkan.

Setelah tujuan dan isi kurikulum, aspek untuk dapat melihat kurkulum adalah dari aspek strategi pencapaian tujuan yang telah ditetapkan atau lebih dikenal dengan metodologis kurikulum. Aspek metodologis kurikulum memiliki peran sebagai cara atau strategi mencapai tujuan. Misalnya menggunakan metode belajar dan mengajar seperti antara lain mastery learning, student active learning, quantum learning dengan mendayagunakan teknologi informasi, video, CD ROM dsb.

Aspek lain untuk melihat kurikulum adalah bagaimana cara kurikulum itu menilai siswanya. Dalam sejarah perkembangan kurikulum Indonesia, evaluasi dilakukan dengan cara-cara berbeda. Sebagai contoh adalah penerapan Ujian Nasional (UN) yang membuat polemik berkepanjangan. Namun demikian, terlepas dari pemahaman mengenai penyusunan kurikulum yang ada, fakta di lapangan mengindikasikan kurikulum pendidikan yang ditetapkan juga belum sinkron dengan persoalan yang tengah dihadapi masyarakat. Misalnya belum siapnya lulusan sekolah terjun bekerja. Bahkan Iulusan perguruan tinggi sekalipun belum siap terjun bekerja. Itu terindikasi dari cukup tingginya angka pengangguran intelektual atau mereka yang berpendidikan tinggi. Berdasarkan 
catatan, sekitar 13\% penduduk berpendidikan akademi ke atas tidak bekerja (BPS, 2005).

Fakta lain adalah ketidaksesuaian dengan kurikulum pendidikan dengan persoalan yang tengah dihadapi masyarakat, misalnya manfaat nyata bagi daerah tempat sekolah itu berada, khususnya daerah di pedesaan, terisolasi, dan pedalaman. Ini mencerminkan adanya kesenjangan antara kemampuan sekolah dan kebutuhan masyarakat. Oleh karena itu, kurikulum harus mampu melakukan kegiatan-kegiatan kreatif dan konstruktif, dalam arti harus menyusun atau mendesain pengalaman belajar yang bersumber dari masyarakat dan berbuat dalam bentuk mata pelajaran yaitu disajikan kepada anak didik. Upaya ini dapat membantu mengembangkan seluruh potensi yang ada pada anak.

Banyak faktor yang harus dipertimbangkan dalam mengembangkan kurikulum seperti Ralp Tyler tekankan yaitu kurikulum mesti dikembangkan berdasarkan prinsipprinsip, relevansi, efektifitas dan efisiensi, kontinuitas, fleksibilitas, integritas, dan kontinuitas (Ralph Tyler dalam Subandijah, 1993). Prinsip relevansi ini memandang bahwa pendidikan sebagai investasi sumber daya manusia yang seharusnya relevan terhadap tuntutan dan kebutuhan masyarakat.

UU Sisdiknas nomor 23/2003 tampaknya sudah memberikan penekanan yang señalan dengan pemandangan di atas walaupun harus diuji dalam pelaksanaannya. UU ini menyatakan bahwa kurikulum disusun dengan memperhatikan peningkatan potensi, kecerdasan, dan minat peserta didik; keragaman potensi daerah dan lingkungan; tuntutan pembangunan daerah dan nasional; tuntutan dunia kerja; perkembangan ilmu pengetahuan, teknologi, dan seni; agama; dinamika perkembangan global; dan persatuan nasional dan nilai-nilai kebangsaan.
Sejalan dengan hal di atas, Arief Rachman Hakim menyatakan bahwa perubahan kurikulum yang terjadi di Indonesia dewasa ini salah satunya dipengaruhi oleh ilmu pengetahuan itu sendiri selalu berkembang (Arief Rachman Hakim, seperti dikutip dari situs Depkominfo, tahun 2007). Lebih jauh, Hakim menjelaskan bahwa perubahan tersebut juga dinilainya dipengarungi oleh kebutuhan manusia dari ilmu tersebut yang selalu berkembang, sementara perkembangan manusia yang selalu berubah juga pengaruh dari luar, dimana secara menyeluruh kurikulum itu tidak berdiri sendiri, tetapi dipengaruhi oleh ekonomi, politik dan kebudayaan.

Oleh karena itu, prinsip pengembangan kurikulum menurut Sudirman juga harus memperhatikan efektifitas, efisiensi, fleksibilitas, dan integritas (Sudirman, 1977). Kurikulum harus dapat dilaksanakan dengan baik atau efektif. Kegiatan kurikuler mendayagunakan waktu, tenaga, biaya dan sumber-sumber lain secara cermat dan tepat sehingga hasil kegiatan kurikuler itu mewadahi dan memenuhi harapan (efisiensi).

Di samping itu, kurikulum harus memberikan kebebasan bertindak (fleksibel). Dalam kurikulum pengertian itu dimaksudkan kebebasan dalam memilih program-program pendidikan bagi murid dan kebebasan dalam mengembangkan program pendidikan bagi para guru. Prinsip terakhir adalah prinsip integritas yang berarti ada upaya agar pendidikan dalam suatu kurikulum menghasilkan manusia seutuhnya walaupun kegiatan kurikulernya terjabar dalam komponen kurikulum.

Kurikulum sebagai wahana yang dinamis perlu dikembangkan terus menerus dan berkesinambungan dalam pengembangan kurikulum saling terkait antara berbagai tingkat dan jenis program pendidikan atau bidang studi. 


\section{B. HASIL DAN PEMBAHASAN}

Pembahasan analisis perkembangan kurikulum pendidikan dasar dan menengah di Indonesia sejak 1968-2006 ini meliputi desain kurikulum, pendekatan metodologis dan evaluasi.

\section{Desain Kurikulum}

Agar dapat melihat bentuk suatu kurikulum, lihatlah pada desain kurikulum.

Desain kurikulum adalah rancangan yang disusun untuk mengkaitkan tujuan kurikulum dengan strategi pelaksanaan kurikulum itu sendiri. Dalam sejarahnya, setiap kurikulum memiliki keunikan sendiri dalam menjabarkan desainnya seperti tergambar dalam tabel 1. Sebagai awal pembahasan adalah kurikulum 1968 yang memiliki upaya keterkaitan antara pendidikan pra sekolah hingga perguruan tinggi.

Table 1. Perbedaan desain kurikulum dan kualifiksi kurikulum 1969-2006

\begin{tabular}{|c|c|}
\hline Tahun & $\begin{array}{l}\text { Aspek } \\
\text { Desain kurikulum }\end{array}$ \\
\hline 1968 & $\begin{array}{l}\text { Menuju ke integrasi kurikulum dari TK s.d. PT. Tiap segi pendidikan dicantumkan } \\
\text { tujuan dan pedoman pelaksanaan dan cara merangsang agar anak melakukan } \\
\text { kegiatan yang aktif }\end{array}$ \\
\hline 1975 & $\begin{array}{l}\text { Pendekatan Prosedur Pengembangan Sistim InstruksionalModel satuan Pelajaran, } \\
\text { Bimbingan dan Penyuluhan, Administrasi dan Supervisi }\end{array}$ \\
\hline 1984 & $\begin{array}{l}\text { Pendekatan PPSI (Prosedur Pengembangan Sistim Instruksional dan Model Satuan } \\
\text { PelajaranMenggunakan konsep CBSA.Lengkap dengan pedoman : Metode, } \\
\text { evaluasi, bimbingan administrasi dan supervisi. }\end{array}$ \\
\hline 1994 & $\begin{array}{l}\text { Pendekatan PPSI (Prosedur Pengembangan Sistim Instruksional) dan Model } \\
\text { Satuan PelajaranKonsep yang lebih menitikberatkan kepada aspek kognitifTidak } \\
\text { memiliki arah pencapaian yang jelas. }\end{array}$ \\
\hline 2004 & $\begin{array}{l}\text { Penyusunan kurikulum pada tingkat satuan pendidikan jenjang pendidikan dasar } \\
\text { pada panduan yang disusun oleh BSNP (Badan Standar Nasional } \\
\text { Pendidikan)Mengembangkan kurikulumdan silabusPerencanaan proses } \\
\text { pembelajaran meliputi pelaksanaan pembelajaran, materi ajar, metode pengajaran, } \\
\text { sumber belajar, dan evaluasi hasil belajar }\end{array}$ \\
\hline 2006 & $\begin{array}{l}\text { Kurikulum ini berisi delapan standar yaitu standar isi, proses, kompetensi lulusan, } \\
\text { tenaga kependidikan, sarana dan prasarana, pengelolaan, pembiayaan dan } \\
\text { evaluasi pendidikan. Standar isi di kembangkan dalam Penyusunan Rancangan } \\
\text { Pelaksanaan Pembelajaran (RPP) yang disusun oleh sekolah atau guru. }\end{array}$ \\
\hline
\end{tabular}

a. Kurikulum 1968

Ada keinginan kuat dari semangat yang ditimbulkan dalam kurikulum 1968 yaitu berupaya mengintegrasikan kurikulum dari pra sekolah atau taman kanak-kanak sampai dengan perguruan tinggi. Ini dilakukan dengan harapan adanya keterkaitan antara pendidikan dasar hingga perguruan tinggi. Kemudian setiap segi pendidikan dicantumkan tujuan dan pedoman pelaksanaan dan cara merangsang agar anak melakukan kegiatan yang aktif. Faktanya memang belum memberikan hasil yang diinginkan. Siswa lebih banyak pasif dan guru lebih banyak aktif. Guru lebih banyak 
dianggap sebagai pusat pendidikan, bukan siswanya.

\section{b. Kurikulum 1975}

Pada kurikulum 1975 mulailah dilakukan penataan yang lebih struktural terhadap desain kurikulum yaitu dengan mengembangkan apa yang dikenal sebagai Pendekatan Prosedur Pengembangan Sistim Instruksional (PPSI). Pendekatan ini berisi langkah-langkah sistematis dalam mengelola pembelajaran yang lebih baik. Produk dari pendekatan ini adalah dikembangkannya model satuan pelajaran, di mana guru harus dapat mengembangkan kurikulum satuan pelajaran setiap materi pelajaran yang ingin diajarkan di kelas. Satuan pelajaran ini berisi dari penjabaran kurikulum nasional ke dalam kurikulum yang dapat diaplikasikan di kelas, uraian materi, penentuan metode pelajaran, penentuan media dan evaluasi pelajaran.

Langkah di atas ditempuh dengan harapan memberikan struktur yang jelas. Setiap guru harus membuat satuan pelajaran yang berisi rincian petunjuk umum, tujuan instruksional khusus (TIK), materi pelajaran, alat pelajaran, kegiatan belajar-mengajar, dan evaluasi. Kurikulum 1975 banyak dikritik. Guru dibikin sibuk menulis rincian apa yang akan dicapai dari setiap kegiatan pembelajaran.

Di samping itu, kurikulum 1975 berisikan model bimbingan dan penyuluhan, administrasi, dan supervisi. Model bimbingan dan penyuluhan ini berupaya agar dapat memberikan bantuan kepada siswa agar dapat belajar dengan baik.

Dalam sejarah perkembangan kurikulum di Indonesia, inilah pertama kali model bimbingan dan penyuluhan dikembangkan. Model ini diadposi dari model pembelajaran negara Barat yaitu guidance and counceling yang berupaya memberikan bantuan terutama psikis kepada siswa agar dapat belajar dengan baik. Pada kurikulum 1975 ini juga dikembangkan model administrasi dan supervisi yang berupaya menata proses pendidikan di sekolah berjalan dengan baik dengan diikuti oleh supervisi oleh para pengawas dan penilik pendidikan.

\section{c. Kurikulum 1984}

Kurikulum 1984 merupakan penyempurnaan kurikulum 1975. Pada kurikulum 1984 ini Pendekatan Prosedur Pengembangan Sistim Instruksional (PPSI) disempurnakan dengan menjabarkan model satuan pelajaran yang berkonsep Cara Belajar Siswa Aktif (CBSA). Konsep ini adalah konsep yang dikembangkan dengan mengadopsi model satuan pelajaran di Inggris yaitu dengan menekankan pada upaya guru untuk mendorong siswa agar belajar dengan lebih mandiri dan aktif.

Ada perubahan paradigma yang signifikan dalam kurikulum ini yaitu perubahan pusat pembelajaran yang sebelumnya adalah menekankan pada aspek guru atau teacher centered kepada student centered atau siswa yang menjadi pusat atau subyek pembelajaran. Konsep ini dianggap berhasil di lokasi-lokasi yang menjadi lokasi perintisan, tetapi sayangnya gagal dikembangkan secara nasional. Konsep CBSA menghendaki adanya sumber belajar yang memadai seperti lembar soalsoal yang harus diisi siswa. Secara nasional konsep sulit dikembangkan karena keterbatasan biaya dan pemahaman guru terhadap konsep ini yang dianggap membuang-buang waktu dan biaya. Kurikulum 1984 ini juga memberikan pedoman metode, evaluasi, bimbingan administrasi dan supervisi. 


\section{d. Kurikulum 1994}

Pendekatan

Prosedur

Pengembangan Sistim Instruksional dan Model Satuan Pelajaran yang dikembangkan sejak kurikulum 1975 kembali diterapkan dalam kurikulum 1994. Ada yang berbeda pada kurikulum ini yaitu adanya pengembangan konsep yang lebih menitikberatkan kepada aspek kognitif. Siswa lebih banyak belajar pada ranah kognitif, sementara ranah afektif dan psikomotor kurang ditekankan. Walaupun penekanan utama kurikulum ini adalah kognitif, tapi uniknya, ada kebijakan Menteri Pendidikan dan Kebudayaan saat itu yaitu Wardiman Pusponegoro yang menginginkan adanya keterkaitan antara apa yang dipelajari sekolah dengan kebutuhan dunia kerja. Kebijakan itu disebut dengan Link and Match atau keterkaitan dan kesepadanan antara pendidikan dengan kebutuhan masyarakat dan dunia kerja. Namun sayangnya, bila kebijakan ini dapat diterapkan tentunya siswa tidak hanya mengandalkan kognitif tetapi lebih dari itu adalah seluruh aspek belajar harus memiliki porsi yang seimbang.

Pada tahun 2004 telah dimulai era baru dalam penyusunan kurikulum yaitu dengan kehadiran yaitu kehadiran Badan Standar Nasional Pendidikan (BSNP). Badan inilah yang berperan memberikan panduan penyusunan kurikulum yaitu pada tingkat satuan pendidikan jenjang pendidikan dasar. Berdasarkan panduan tersebut, pemerintah menyusun kurikulum yang disebut Kurikulum Berbasis Kompetensi (KBK).

Kurikulum ini mengembangkan kurikulum dengan merinci silabussilabus yang dijadikan dasar pengembangan satuan pelajaran. Satuan pelajaran atau yang dikenal perencanaan proses pembelajaran meliputi pelaksanaan pembelajaran, materi ajar, metode pengajaran, sumber belajar,dan evaluasi hasil belajar. Dalam kurikulum 2004 ini, para murid dituntut aktif mengembangkan keterampilan untuk menerapkan ilmu pengetahuan secara kolektif, meski sesungguhnya antar siswa saling berkompetisi. Peran guru sebagai fasilitator yang memberikan peluang dan kemudahan siswa belajar. Di kelas, para siswa bukan lagi objek, namun subjek. Kegiatan-kegiatan dilakukan, dan guru mesti mengukurnya. Oleh karena itu setiap kegiatan siswa ada nilainya.

\section{Pendekatan Metodologis}

Sejak kurikulum 1968 hingga 2006, setiap kurikulum memiliki perbedaan pendekatan metodologis. Pendekatan metodologis adalah pendekatan yang dilakukan berkaitan dengan bagaimana siswa belajar di sekolah. Sebagai contoh kurikulum 1968 lebih mengutamakan hafalan. Dalam teori pembelajaran, hapalan adalah tingkat terendah dari aspek kognitif. seperti diketahui menurut taksonomi Benjamin Bloom, aspek kognitif merupakan salah satu ranah pembelajaran yang memiliki tingkatan yaitu hapalan, pemahaman, aplikasi, sintesa, analisa, dan evaluasi.

Hapalan yang dilakukan pada kurikulum 1968 ini adalah hal-hal yang dianggap penting untuk kehidupan kelak walaupun faktanya siswa lebih banyak menghapal ketimbang memahami materi pelajaran secara menyeluruh. Pelajaran yang diajarkan lebih mengarah kepada book centered, artinya masih berdasarkan kepada buku pelajaran. Tidak adanya inovasi-inovasi yang dilakukan oleh guru, sehingga proses pembelajaran banyak menggunakan kalimat verbal, tanpa menggunakan media atau alat-alat yang memadai. Kondisi kelas lebih dikuasai guru secara otokrasi dan kebanyakan siswa belajar didorong oleh rasa takut (linat tabel 2).

Kurikulum 1975 lebih mengutamakan penguasaan kognitif dan kurang merangsang siswa untuk berfikir. Selain 
Tabel 2. Pendekatan metodologis kurikulum 1968 - 2006

\begin{tabular}{|c|c|c|}
\hline \multirow{2}{*}{ Tahun } & \multicolumn{2}{|l|}{ Aspek } \\
\hline & Pendekatan metodologis & Evaluasi \\
\hline 1968 & Tradisional dan Hapalan & Sistem Ujian Negara. \\
\hline 1975 & Tradisionil (guru aktif, murid pasif) & Sistem Ujian Negara \\
\hline 1984 & $\begin{array}{l}\text { Berorientasi pada tujuan, efesiensi dan efektivitas, } \\
\text { relevansi dengan kebutuhan, keluwesan dan } \\
\text { keadaan,Evaluasi formatif dansumatif. } \\
\text { pendidikan seumur hidup. }\end{array}$ & EBTA, EBTANAS. \\
\hline 1994 & $\begin{array}{l}\text { Teacher Centered (Tidak memiliki arah pencapaian). } \\
\text { Kurikulum } 1994 \text { menghendaki guru lebih kreatif, } \\
\text { namun aktivitas guru sebatas mengajarkan apa } \\
\text { yang sudah ditetapkan dalam kurikulum. }\end{array}$ & EBTA, EBTANAS \\
\hline 2004 & $\begin{array}{l}\text { Student centered dan guru berfungsi sebagai } \\
\text { fasilitator serta menggunakan CTL (Contextual } \\
\text { Teaching and Learning). Kurikulum } 2004 \text { atau } \\
\text { belajar } \\
\text { Kurikulum Berbasis Kompetensi (KBK), siswa } \\
\text { dituntut lebih kreatif. Guru harus bisa "memaksa" } \\
\text { siswa untuk memberi feedback dalam setiap } \\
\text { pembelajaran. }\end{array}$ & $\begin{array}{l}\text { Evaluasi hasil belajar oleh } \\
\text { pendidik (UH) Ulangan } \\
\text { Harian; Evaluasi hasil } \\
\text { oleh satuan pendidikan } \\
\text { (UAS) Ujian Akhir Sekolah; } \\
\text { Evaluasi hasil oleh } \\
\text { pemerintah (UN) Ujian } \\
\text { Nasional }\end{array}$ \\
\hline 2006 & $\begin{array}{l}\text { Kurikulum } 2006 \text { hanya memberikan standar isi dan } \\
\text { standar kelulusan bagi siswa. Guru atau sekolah dan } \\
\text { masyarakat setempatlah yang dituntut untuk } \\
\text { mengembangkan kurikulum sendiri sesuai potensi } \\
\text { sederajat. } \\
\text { dan keinginan sekolah. }\end{array}$ & $\begin{array}{l}\text { Ujian NasionalUN SMP/ } \\
\text { sederajat, SMA/sederajat, } \\
\text { dan tahun } 2008 \text { SD/ }\end{array}$ \\
\hline
\end{tabular}

dari itu, bahan pelajaran biasanya sudah ditetapkan, bahkan guru hanya melaksanakannya walaupum di dalam kurikulum ini ada juga motivasi untuk merangsang siswa dalam berfikir sendiri secara kritis walaupun dalam batas-batas tertentu. Penggunaan metode pembelajaran kurikulum 1975, masih menggunakan separated subject curriculum, sehingga pola berfikir anak lebih cenderung statis.

Hal berbeda terjadi pada Kurikulum 1984 yang memberikan nuansa pendidikan yang bulat (jasmaniah, rohaniah, sosial, emosional, dan juga intelektual) dibandingkan dengan kurikulumkurikulum sebelumnya, keikutsertaan siswa untuk memecahkan soal-soal sehingga terjalin kerjasama yang baik antara guru dengan siswa. Adapun pelajaran dipadukan dan bertalian erat satu sama lain, lebih berorientasi pada life centered artinya lebih mempelajari kehidupan, metode ini dikenal dengan istilah CBSA (Cara Belajar Siswa Aktif). Pembelajaran ini juga mulai menggunakan alat-alat yang kongkret tidak abstrak, serta peran guru yang memberikan bimbingan kepada setiap siswa menurut kebutuhannya. Jadi, sistem yang dikembangkan adalah sistem belajar tuntas dan evaluasi secara menyeluruh yang merangkul tiga ranah yaitu; ranah kognitif, afektif, dan psikomotor. 
Kurikulum 1994 lebih berorientasi pada content mastery, yaitu lebih menekankan pada penguasaan materi pelajaran agar target kurikulum dapat terselesaikan sesuai dengan yang digariskan di dalam GBPP (Garis-Garis Besar Program Pengajaran) tanpa ada pendalaman yang memadai. Akibatnya guru menjadi sumber ilmu bagi peserta didik sehingga kurang memperdulikan apakah materi yang disampaikan dipahami atau tidak. Yang terpenting adalah mengalihkan apa yang ada didalam Garis-Garis Besar Program Pengajaran (GBPP) ke dalam otak siswa. Ditinjau dari aspek capaian domain pembelajaran, kurikulum 1994 lebih menekankan kepada aspek kognitif, semua isi ditetapkan oleh pusat, yang dituangkan ke dalam GBPP secara rinci.

Dalam kurikulum 2004, guru diberikan kebebasan melakukan improvisasi dalam pendekatan pembelajaran. Di dalam hal ini, guru harus memberdayakan seluruh potensi dan kemampuan anak didik secara optimal. Menurut Indra Jati, paradigma pembelajaran yang dinyatakan oleh UNESCO sejalan dengan $\mathrm{KBK}$, yaitu: learning to know, learning to do, learning to live together, and learning to be. (Indrajati, 2004). Kurikulum ini merangkul tiga aspek yaitu, kognitif afektif, dan psikomotor. Dilihat dari kegiatan pembelajaran KBK, lebih memfokuskan pada kegiatan pembelajaran yang menyenangkan. Kegiatan ini diyakini sangat membantu anak dalam menangkap pelajaran. Adanya dialog dinamis dan konstruktif antara guru dan siswa, tidak lagi monoton seperti ceramah yang membosankan anak sebagaimana yang terjadi pada kurikulum sebelumnya.

Dalam sejarah kurikulum Indonesia, kurikulum 2006 inilah yang pertama kali disusun dalam bentuk standar isi dan standar kelulusan. Artinya gurulah yang menyusun kurikulum sendiri untuk sekolahnya. Konsekensinya setiap sekolah harus memiliki kurikulum sendiri. Hal dilandasi pemikiran bahwa setiap sekolah memiliki kemampuan yang berbeda satu sama lain dalam memahami potensinya dan daya kelola proses pendidikannya. Pendekatan metodologis kurikulum ini berbeda dengan kurikulum sebelumnya. Kurikulum ini memiliki standar kurikulum masing-masing untuk tingkatan yaitu kurikulum tingkat satuan pendidikan (KTSP) Sekolah Dasar, KTSP SMP, KTSP SMA. Chaedar Alwasilah memberikan sedikitnya enam alasan sebagai berikut seperti dikutip dari situs harian Republika. (Alwasilah pada situs Republika, 2007).

Pertama adalah kurikulum ini menekankan konsep besar, lalu diikuti konsep-konsep kecil. Kemudian, kegiatan kurikuler mengandalkan sumber-sumber data primer dan juga materi-materi buatan yang bermakna yang tentunya telah tersedia dan mudah disediakan oleh sekolah, seperti alam sekitar, atau buku teks. Jadi menghindari mengadakan sumber belajar yang sulit dan tak terjangkau dari segi fisik, teknis, dan juga pembiayaan. Ketiga, kurikulum ini memperlakukan siswa sebagai pembelajar yang potensial, dan mendorongnya untuk memiliki keberanian bertanya dan berdebat. Oleh karena itu guru harus mengajar secara interaktif dan dialogis. Ini tantangan bagi guru yang selama ini yang hanya lebih banyak menghabiskan waktunya untuk berceramah di depan kelas. Guru bersama siswa bersama membangun pembelajaran agar dapat memahami pelajaran. Keempat, pola mengajar guru menjadi interaktif, yakni antara lain dengan kepandaian menerjemahkan lingkungan sekitar sehingga dapat dipahami siswa. Ini berbeda dari guru tradisional yang cenderung monologis dalam menyebarkan informasi kepada siswa.

Selanjutnya, guru berupaya memahami kadar pengetahuan siswa saat ini untuk dijadikan pijakan bagi pelajaran yang akan datang. Ini berbeda dari kelas tradisional, di mana guru mencari jawaban yang benar untuk memvalidasi 
pembelajaran siswa. Pembelajaran konstruktivis membangun ketersambungan antara pelajaran sebelumnya dengan pelajaran selanjutnya. Terakhir, siswa bekerja dalam kelompok-kelompok kecil, guru dan pengembang kurikulum pun berkolaborasi dengan para pemangku peran dalam merumuskan KTSP.

\section{Evaluasi}

Evaluasi merupakan aspek penting dalam kurikulum. Dalam setiap kurikulum ada evaluasi. Dalam kurikulum 1968 dan 1975, evaluasi yang dilakukan adalah sistem ujian negara. Setiap siswa dianggap Iulus dalam suatu tingkat pendidikan setelah mengikuti ujian negara. Sebelum mengikuti ujian negara ini, setiap siswa tentunya harus mengikuti ujian sekolah sebagai syarat untuk mengikuti ujian negara. Dalam ujian negara ini tidak dikenal dengan evaluasi formatif.

Pada kurikulum 1984 dan 1994, sistem ujian negara sudah ditinggalkan. Evaluasi dilakukan dengan pemberian evaluasi formatif dan summatif. Evaluasi formatif adalah evaluasi yang dilakukan pada tengah pembelajaran yang bertujuan untuk mengetahui sejauh mana siswa dapat memahami materi pelajaran yang dipelajari. Di samping itu evaluasi formatif itu juga memberikan feedback bagi guru dalam memperbaiki proses pembelajaran yang tengah dilakukan. Pada kurikulum ini pertama kali diterapkan evaluasi sekolah dan evaluasi nasional. Evaluasi sekolah dikenal dengan nama Evaluasi Belajar Tahap Akhir (EBTA) dan evaluasi nasional dikenal dengan Evaluasi Belajar Tahap Akhir Nasional (EBTANAS). Setiap siswa harus mengikuti dan lulus EBTA dan EBTANAS dalam suatu tingkat pendidikan.

Sementara hal berbeda terjadi pada Kurikulum KBK yaitu memiliki struktur evaluasi hasil belajar oleh pendidik yaitu ulangan harian $(\mathrm{UH})$, evaluasi hasil belajar oleh satuan pendidikan atau ujian akhir sekolah (UAS), dan evaluasi hasil oleh pemerintah atau ujian nasional (UN). Ulangan harian adalah kegiatan yang dilakukan secara periodik untuk mengukur pencapaian kompetensi siswa setelah menyelesaikan suatu tujuan pelajaran tertentu. Di setiap akhir masa satuan pendidikan, seorang siswa harus mengikuti ujian akhir sekolah. Evaluasi hasil belajar oleh satuan pendidikan ini dilakukan oleh sekolah untuk selanjutnya dapat mengikuti evaluasi hasil oleh pemerintah atau ujian nasional. Pada kurikulum KBK ini ujian nasional hanya diterapkan pada tingkat SMP/sederajat dan SMA/sederajat. Sementara tingkat SD belum dlaksanakan. Penerapan ujian nasional belakangan menjadi polemik yang berkepanjangan di masyarakat.

Kurikulum 2006 atau kurikulum Standar Isi/Standar Kelulusan masih menetapkan ujian nasional sebagai acuan evaluasi dari sistem pendidikan nasional, walaupun kurikulum 2006 bukan lagi menjadi kurikulum nasional. Sistem evaluasi pada kurikulum 2006 tidak banyak berbeda dengan evaluasi kurikulum KBK yaitu masih diterapkannnya evaluasi UAS dan Ujian Nasional. Ada keinginan yang dicapai dalam kurikulum 2006 ini yaitu tidak hanya pencapaian kuantitas siswa yang bersekolah tetapi juga ingin meningkatkan kualitas pendidikan itu sendiri. Oleh karena itu di tahun 2008 direncanakan ujian nasional tingkat SD.

\section{KESIMPULAN}

Perubahan kurikulum dapat dilihat dari sedikitnya tiga aspek yaitu pendekatan metodologis, desain kurikulum, pendekatan metodologis, dan evaluasi. Perubahan kurikulum terjadi karena adanya perbedaan dari para penyusun dan termasuk pemerintah dalam melihat pendidikan itu sendiri. Dari hasil dan pembahasan dapat disimpulkan bahwa: 
1. Desain kurikulum 1968, 1975, 1984 , 1994, 2004, dan 2006 adalah memiliki pedoman pelaksanaan bagi guru untuk dapat melaksanakan pembelajaran. Pedoman ini memiliki struktur yang berbeda terutama dari segi penjabarannya kepada siswa. Kurikulum 1975, 1984 dan 1994 memiliki desain yang sama yaitu memiliki PPSI tetapi kurikulum 1984 memiliki penekannya yang berbeda yaitu CBSA. Sementara kurikulum 2006 hanya berisi panduan penyusunan kurikulum dan gurulah yang menjabarkannya.

2. Perbedaan pendekatan metodologis kurikulum 1968, 1975, 1984, 1994, 2004, dan 2006 adalah dari segi memandang siswa sebagai subyek pendidikan. Kurikulum 1968 dan 1975 masih memilki pendekatan teacher centered di mana guru sangat berperan, sementara kurikulum 1984 hingga 2006 telah ada kemajuan yaitu pergeseran pandangan siswa sebagai subjek pendidikan walaupun belum sepenuhnya dilaksanakan.

3. Perbedaan evaluasi kurikulum 1968, 1975, 1984, 1994, 2004, dan 2006 adalah dari segi keberadaan dan cara menilai siswa. Evaluasi pada kurikulum 1968 dan 1975 memiliki sistem evaluasi yang mirip yaitu adanya ujian negara. Kurikulum 1984 dan 1994 berubah dengan adanya evaluasi formatif dan sumatif dan adanya EBTA dan EBTANAS. Sedangkan kurikulum 2004 dan 2006 ditandai dengan adanya ulangan harian, UAS dan Ujian Nasional untuk SMP dan SMA atau yang sederajat.

\section{DAFTAR PUSTAKA}

Ahmad. H.M. Pengembangan Kurikulum, Bandung: CV Pustaka Setia.1999.

Balitbang Depdiknas, Jurnal Pendidikan dan Kebudayaan, Tahun ke-11, No.057. Depdiknas, Jakarta 2005.

Djojonegoro, Wardiman. Lima Puluh Tahun Perkembangan Pendidikan Indonesia, Jakarta: Depdikbud, 1996.

Hamalik, Oemar. Pengembangan Kurikulum; Dasar-Dasar dan Perkembangannya, Bandung:Mandar Maju, 1990.

Kurikulum Pendidikan Dasar dan Menengah, Depdikbud, Jakarta 1968

Kurikulum Pendidikan Dasar dan Menengah, Depdikbud, Jakarta 1975

Kurikulum Pendidikan Dasar dan Menengah, Depdikbud, Jakarta 1984

Kurikulum Pendidikan Dasar dan Menengah, Depdikbud, Jakarta 1994

Kurikulum Pendidikan Dasar dan Menengah, Depdiknas, Jakarta 2004

Kurikulum Tingkat Satuan Pendidikan, Depdiknas, Jakarta 2006

Ladjid, H. Hafni. Pengembangan kurikulum; Menuju Kurikulum berbasis Kompetensi, Quantum Teaching, Jakarta 2005.

Nasution, S, Asas-asas Kurikulum. Bumi Aksara, Cet-4, Jakarta 2001.

Nurgiantoro, Burhanudin. Dasar - Dasar Pengembangan Kurikulum Sekolah BPFE, Jogjakarta, 1988.

Syaodih, S, Nana. Pengembangan Kurikulum, Teori dan Praktek, Bandung : PT Remaja Rosdakarya, 1997.

Subandijah, Pengembangan dan Inovasi Kurikulum, Jakarta: Rajawali, 1993.

S, Sudirman. Pembinaan dan Pengembangan Kurikulum, Depdikbud: Jakarta, 1977.

Undang-Undang no. 20 th. 2003 tentang Sisdiknas, Depdiknas, Jakarta, 2005.

Webster's International Dictionary.

h t t p : / / w w w. re p u b l i k a . c o . i d / online_detail.asp?id=243820\&kat_id=23 28 September 2007.

http://www.depkominfo.go.id, 27 September 2007. 